\title{
Does Board Collective Suitability Affect Performance and Risk? Evidence from European Banks
}

\author{
Maria Luisa Di Battista ${ }^{1}$, Laura Nieri ${ }^{2}$, Marina Resta ${ }^{2} \&$ Alessandra Tanda ${ }^{3}$ \\ ${ }^{1}$ Università Cattolica del Sacro Cuore, Piacenza (PC), Italy \\ ${ }^{2}$ Department of Economics, University of Genoa, Genova (GE), Italy \\ ${ }^{3}$ Department of and Management, University of Pavia, Pavia (PV), Italy \\ Correspondence: Alessandra Tanda, Department of Economics and Management, University of Pavia, Via San \\ Felice 5, Pavia (PV). Italy. Tel. 00390-382-986-126.
}

Received: November 18, 2021

Accepted: December 17, 2021

Online Published: January 5, 2022

doi:10.5539/ijef.v14n2p1

URL: https://doi.org/10.5539/ijef.v14n2p1

\begin{abstract}
This paper analyzes the features of the boards of large listed European banks and their degree of "collective suitability" as formalized by the Capital Requirements Directives (CRD4) and evaluates whether closer proximity to the collective suitability regulatory paradigm affects banks' performance, risk and risk-adjusted performance. We leverage Self-Organizing Maps (SOMs) to analyze board features and suitability (i.e. competence, diversity, independence and time commitment) jointly as a multifaceted, non-linear combination of all board variables, rather than evaluating the single variables individually as in the mainstream literature. Using a hand-collected dataset based on numerous features of boards of directors, we find that European banks' boards can be classified in four different board archetypes characterized by different degrees of collective suitability. Our findings also suggest positive relationships between the degree of collective suitability and performance, risk-adjusted performance, and risk, confirming that the regulatory provisions on governance are going in the right direction, enhancing effective and prudent management.
\end{abstract}

Keywords: banks, boards, corporate governance, regulation, Self-Organizing Map, suitability

\section{Introduction}

Over the last two decades, the characteristics of the board of directors of banks, their suitability and the relationship between board features and bank performance have attracted increasing attention from academics and regulators for the central role that boards have in bank management and supervision. Any flaws in its functioning may lead to excessive risk-taking and bank instability, as the global financial crisis highlighted (Kirkpatrick, 2009). Appropriate board characteristics are a critical precondition of (good) internal governance that is able to bring value to the bank in terms of not only shareholders' profitability but also stakeholders' interests and effective risk management. Appropriateness has to be considered at the individual level, considering each director's characteristics in terms of reputation, competence, time commitment, etc., and the collective level, which concerns the overall suitability of the board to perform its management and supervisory functions. Although the suitability of each director is an important requirement, it is the collective and overall suitability of the board that is crucial in the decision-making process, as the responsibilities of the management body in its functions are collective.

In line with this approach, the European banking regulatory authorities have gradually reinforced corporate governance rules for banks, specifically in terms of the structure and quality of the board of directors both at individual and "collective" levels. This process led to the issuance of Directive 36/2013 (also known as CRD4), which, for the first time in the banking sector, specified the requirements that should be met by each director and by the board as a whole and formalized a new "bank board paradigm". The expectation is that collective suitability and board diversity enhance the decision-making process and allow for proper and prudent management of the bank and effective risk-taking.

Despite the relevance of the "collective" approach, most studies of banks' corporate governance have not yet addressed this topic exhaustively, and the empirical evidence concerning the relationship between the board's overall characteristics and performance and/or risk is rather scant. This can be explained by several practical 
hurdles, including the difficulties in identifying appropriate/meaningful proxies for characteristics such as skills, expertise, specific competencies in banking and finance (Blinco, Galbarz, Hohl, \& Zamil, 2020); understanding how all the different qualities of the board combine together; and finding indicators that synthesize the overall features of the board. In fact, there are no a priori hypotheses about how the different features of the board combine with one another; in consequence, most studies focus on the effect of specific board features, which they analyze separately from the others, thus failing to gauge the potential interrelationships among the different characteristics of the board. This paper aims to fill these gaps by investigating the collective suitability and appropriateness of bank boards with reference to a sample of European banks. It provides two main novel contributions. First, it jointly analyzes how the different features of the board combine with one another and identifies a number of "board archetypes" employing a suitable technique, i.e., Self-Organizing Maps (SOMs, a machine learning technique) able to explore a large number of board attributes jointly and to consider the board as a single entity, not merely the sum of its characteristics, thus providing a new perspective for analyzing the collective features of the board. Levering on a comprehensive hand-collected dataset covering over 700 directors of 40 listed European banks, the paper assesses whether the features of the different archetypes and their degree of collective suitability impact banks' financial performance and risk control. Furthermore, we assess the relationship between governance and different measures of performance, risk and risk-adjusted performance measures.

The remainder of the paper is structured as follows: the second section delves into the concept of collective suitability with specific reference to European banking regulations and prior research, and describes our aims; the third section explains the methodology and data used in the empirical analysis; the fourth section presents and discusses our results; and the last section concludes.

\section{Regulatory Context, Prior Research, and Aims of the Paper}

\subsection{The Issue of Collective Suitability and European Banking Regulations}

Weak board governance has been blamed for having played a pivotal role in the development and outbreak of the international financial crisis: among other factors, the directors' lack of financial experience and inability to understand the most complex aspects of bank management, as well as insufficient board diversity and limited ability to challenge senior managers' decisions, led to ineffective bank management and fostered instability in the banking system (Financial Stability Board [FSB], 2013; Mehran, Morrison, \& Shapiro, 2011). Consequently, in the aftermath of the crisis, regulators have focused increasingly on improving bank corporate governance regulation to facilitate the implementation of sound practices and ensure the effective and prudent management of institutions (Basel Committee on Banking Supervision [BCBS], 2015).

In Europe, internal bank governance was covered by Article 22 of Directive 2006/48/EC, which required, in very general terms, that every credit institution have robust governance arrangements, and by the guidelines on internal governance issued in 2011 by the European Banking Authority (EBA), which defined a management body's duties and responsibilities but did not explicitly consider the individual and collective requirements that a board should meet. However, regulation was not able to promote sound corporate governance practices for two reasons: i) the very general and often non-binding provisions on governance; and ii) the unclear role of the competent authorities in overseeing governance. The CRD4 introduces the new bank governance paradigm, that formalizes the concept of the suitability and appropriateness of the board and states the requirements the management body needs to meet to be judged suitable by European bank supervisors. The CRD4 clearly indicates the main principles and standards that shareholders should consider (and authorities should oversee) when appointing members of the management body and provides a double-track policy framework, i.e., each board member has to comply with the individual suitability requirements and, more importantly, the board as a whole has to comply with the collective suitability rules (Note 1). In detail, collective suitability attains to five different profiles:

- Competence: overall knowledge, skills, and ability; professional experience; banking and finance competencies; etc.;

- Diversity: in the demographic aspects of board members (age, gender, etc.), as well as their educational and professional backgrounds. It should prevent the phenomenon of groupthink and enhance the decision-making process;

- Independence and balance of power: limits to the concentration of power within the board and presence of an appropriate number of independent and non-executive directors, to protect the interests of the different stakeholders; 
- Time commitment: adequacy of the time spent by the board in performing its functions, which in turn is affected by the number of other mandates/offices held by each director;

- Structure: the size of the board and its governance structure. Although regulators do not claim the superiority of a specific structure, according to the relevant literature, a very small board may not have adequate overall competence and diversity, whereas too large a board may be inefficient.

Overall, collective board suitability requirements are based on the expectations that suitable and diversified boards are able to keep all risks under control, ensure the effective and prudent management of the bank, and allow for better performance at the same time.

Also after the issuance of CRD4, supervisory interventions underlined the relevance of banks' governance and risk management in the supervisory process (FSB, 2017; Blinco et al., 2020). These included "Guidelines on the assessment of the suitability of members of the management body and key function holders" (European Banking Authority-European Securities and Markets Authority [EBA-ESMA], 2017; EBA-ESMA, 2021); the updated "Guide to fit and proper assessments" (European Central Bank [ECB], 2018; ECB, 2021).

\subsection{Prior Research and Aims of the Paper}

There is a wide and fast-growing literature examining the relationship between bank board characteristics and performance. Suitable and diversified boards allow banks to curb risk and achieve better performance according to the traditional theoretical literature (Hermalin \& Wiesbach, 1991, 2003); however, the wide empirical literature provides mixed and contrasting results with respect to the contribution of board features to bank performance (for a review, see de Haan \& Vlahu, 2016; Fernandes, Farinha, Martins, \& Mateus, 2018; John, De Masi, \& Paci, 2016). The latter is usually proxied by returns — and less often by risk measures and risk-adjusted performance (Aebi, Sabato, \& Schmid, 2012; Ellul \& Yerramilli, 2013; Harkin, Mare, \& Crook, 2020; Srivastav \& Hagendorff, 2016); governance is proxied by one or more characteristics of the management body such as size; the percentage of non-executive directors; the directors' nationality, education, and financial expertise; and gender diversity (Resti, 2020). The latter is the most common diversity profiles investigated (e.g., Adams \& Ferreira, 2009; Carter, Simkins, \& Simpson, 2003; Farrell \& Hersch, 2005; Nguyen, Hagendorff, \& Eshraghi, 2015) together with age diversity (e.g., Arnaboldi, Casu, Gallo, Kalotychou, \& Sarkisyan, 2021; Bøhren \& Staubo, 2016; Grove, Patelli, \& Victoravich, 2011), and nationality of directors (e.g., Bennouri, Chtioui, Nagati, \& Nekhili, 2018; García-Meca, García-Sànchez, \& Martínez-Ferrero, 2015; Masulis, Wang, \& Xie, 2012). In general, the evidence shows that greater diversity is associated with better performance and risk management, but results remain ambiguous (Adams \& Ferreira, 2009; Cardillo, Onali, \& Torluccio, 2020; Carter et al., 2003; Farrell \& Hersch, 2005; Nguyen et al., 2015).

The balance of power within the board has also received much attention in academic studies, especially in relation to the $\mathrm{CEO} / \mathrm{Chairman}$ duality effects on risk and performance, providing contrasting evidence (e.g., Altunbaş et al., 2020; John et al., 2016; Schultz, Tan, \& Walsh, 2010). Similarly, the empirical studies analyzing the effect of the presence of independent or non-executive directors on bank performance or risk management, provide inconclusive results (Altunbaş, Thornton, \& Uymaz, 2020; De Andres \& Vallelado, 2008; Pathan \& Faff, 2013).

Finally, another strand of the literature focused on the level of competence and skills of the board, including information on the education and previous experience of directors (e.g., Hau \& Thum, 2009; Locatelli, Schena, Tanda, \& Uselli, 2018). Despite their relevance from a managerial and regulatory point of view, these aspects have so far received limited attention because of the absence of public data and/or standardized measures. Overall, results tend to confirm that the level of experience and education of the board promotes better performance and risk control.

The lack of univocal empirical evidence on the nexus between bank performance and board governance may also be due to the vast majority of the empirical analyses considering each board characteristic independently of the others. In fact, they ignore the possible interdependencies among board features and offer a limited picture of overall board governance. Directors' skills are interdependent (Adams, Akyol, \& Verwijmeren, 2018) and collective suitability of the board is a complex concept that calls for a multidimensional analysis of the different board features and how they interrelate, without a priori hypotheses (Adams et al., 2018; Tarchouna, Jarraya, \& Bouri, 2017).

To delve into this issue, we exploit the definition of collective suitability given by the CRD4 together with a specific technique - SOM - to analyze the features of the boards of 40 European banks. This technique offers an alternative approach to data analysis, considering the bank situation as a multifaceted, non-linear combination of 
all board variables and thus capturing all the possible interrelationships among the multiple characteristics of the board and identifying similarities between bank boards, without imposing rules on the way the board features aggregate. We can thus identify a number of groups of banks sharing similar board features and visualize the resulting patterns (Zou \& Hastie, 2005). These groups represent how the different characteristics of the board combine together and can be viewed as archetypes in terms of board governance.

Finally, after analyzing the extent to which each archetype is close to the collective suitability rules identified by the regulations, we assess whether the board archetype of each bank affects its performance and risk.

\section{Data and Empirical Design}

\subsection{Data}

The empirical analysis is based on a sample of 40 listed banks from 11 Western European countries (see Table 1). For the selected countries, we considered all the domestic banks that were listed at 2014 year-end and for which detailed information on board governance and financial and economic data was available.

Table 1. Sample composition

\begin{tabular}{lcc}
\hline Country & Number of banks & Total assets per country (million euros) \\
\hline Austria & 1 & 196287 \\
Belgium & 2 & 492294 \\
France & 3 & 4974940 \\
Germany & 3 & 2316577 \\
Ireland & 2 & 143748 \\
Italy & 10 & 2168747 \\
Netherlands & 2 & 1379723 \\
Portugal & 2 & 118990 \\
Spain & 6 & 2618997 \\
Sweden & 4 & 1476242 \\
UK & 5 & 6961593 \\
Total & 40 & 22848138 \\
\hline
\end{tabular}

First, we apply SOMs to a dataset that includes 28 variables describing the five profiles of sample boards' collective suitability, i.e., competencies, diversity, time commitment, independence and balance of powers, and the structure of the board, as of the end of 2014 (Table 2, column a). These 28 variables were created by aggregating hand-collected information on each of the 710 members of the boards (Note 2 and Note 3) (Table 2, column b).

Information on the individual board members was retrieved from various sources (annual reports, governance reports, CVs available on the bank websites, and other public sources). We collected information on demographic traits (e.g., gender, age), functioning of the board (independent or executive directors, presence at meetings, number of other offices held), competencies (e.g., education), experience and skills, specific competence in Banking and Finance (Note 4) (Table 2).

The SOM algorithm allows obtaining the board governance archetypes, i.e., different models in terms of board governance. We explore the overall characteristics of each board archetype and evaluate its proximity to the collective suitability regulatory paradigm. Afterwards, we evaluate the relationship between bank financial performance and board archetypes identified by SOMs through a panel regression, employing bank financial data obtained through Orbis Bankfocus and SNL Financial and macroeconomic data retrieved from the World Bank database.

We detail the methodological steps in the following sections. 
Table 2. List of variables for the analysis of board suitability

\begin{tabular}{ll}
\hline $\mathrm{N}$ & a) BOARD FEATURES \\
\hline $1 \%$ DEGREE: Percentage of directors holding a \\
bachelor's degree \\
$2 \%$ POST DEGREE: Percentage of directors with a post \\
graduate degree \\
\% FOREIGN STUDIES: Percentage of directors that \\
have studied abroad \\
\hline 4 B\&F SCORE: Banking \& Finance Score at board level \\
is obtained by averaging all the B\&F Scores obtained \\
for the single directors It is a proxy of the scope of the \\
banking and finance professional competencies of the \\
board
\end{tabular}

$5 \%$ BANK: Percentage of directors that have one or more professional experiences in any banking and finance It proxies the degree of banking and finance knowledge of the board

$6 \%$ SAME: Percentage of directors that have one or more professional working experiences in the same bank in any role

$7 \%$ INTERNATIONAL EXPERIENCE: Percentage of directors with international experience

$8 \%$ BOARD: Percentage of directors that have one or more previous experiences as a board director

\begin{tabular}{lll}
\hline & DIVERSITY \\
\hline 9 & $\%$ WOMEN: Percentage of women in the board & Demographic diversity \\
& & $\begin{array}{l}\text { GENDER: dummy variable equal to one for women directors and zero } \\
\text { otherwise }\end{array}$ \\
10 & $\%$ FOREIGN: Percentage of foreign directors & 10 NATIONALITY: nationality of directors \\
11 & Average age: Average age of directors in the board & 11 AGE of the director \\
\hline & & Diversity in education
\end{tabular}

$12 \%$ BUSINESS \& ECO: Percentage of directors with a 12 DEGREE BUSINESS \& ECONOMICS: dummy variable equal to one degree in Economics, Management, Business, for directors with a degree in Business and Economics and zero Administration, and related courses

13 \% LAW: Percentage of directors with a degree in Law 13 DEGREE LAW: dummy variable equal to one for directors with a or Political science

$14 \%$ STEM: Percentage of directors with a degree in quantitative disciplines (Mathematics, Engineering, Statistics, Physics)

$15 \%$ OTHER DEGREE: Percentage of directors with a 15 OTHER DEGREE: dummy variable equal to one for directors with a degree in other disciplines

$\mathrm{N}$ b) DIRECTORS FEATURES

COMPETENCE

Education

degree and zero otherwise

2 POST DEGREE: dummy equal to one for the directors holding a post degree diploma and zero otherwise

3 FOREIGN STUDIES: dummy equal to one for the directors that have studied abroad for their bachelor or post degree course and zero otherwise

Professional competences

B\&F SCORE: Banking \& Finance score expressing the number of different roles in which the director obtained knowledge on banking and financial issues We assign one point for each experience as either manager, director, consultant, professor/academic, in the same bank or in another bank (or financial institution) If the director has at least one experience in a given category, we assign 1 point If he/she has experiences in all the categories, the score is 5 , the maximum achievable

5 BANK EXPERIENCE: dummy variable equal to one for directors with previous professional experience in banking and finance and zero otherwise

6 SAME BANK EXPERIENCE: dummy variable equal to one for directors with previous working experience in the same bank and zero otherwise

7 INTERNATIONAL EXPERIENCE: dummy equal to one for the directors that have at least one professional experience obtained abroad and zero otherwise

8 BOARD EXPERIENCE: dummy variable equal to one for directors with previous board experience and zero otherwise DIVERSITY otherwise degree in Law or Political Science and zero otherwise

14 DEGREE "STEM": dummy variable equal to one for directors with a degree in quantitative disciplines (Mathematics, Engineering, Statistics, Physics) and zero otherwise degree in other disciplines and zero otherwise Diversity in professional experience

$16 \%$ ACADEMICS: Percentage of directors with 16 PROFESSIONAL EXPERIENCE ACADEMICS: dummy variable equal experience as a university professor/academic to one for directors with a previous professional experience as a university professor/academic and zero otherwise

$17 \%$ CONSULT: Percentage of directors with experience 17 as a legal/fiscal/strategic consultant
17 PROFESSIONAL EXPERIENCE CONSULTANT: dummy variable equal to one for directors with a previous professional experience as a legal/fiscal/strategic consultant and zero otherwise 
$18 \%$ MANAGER: Percentage of directors with 18 PROFESSIONAL EXPERIENCE MANAGER: dummy variable equal experience as a manager, director, executive to one for directors with a previous professional experience as a manager, director, executive and zero otherwise

$19 \%$ ENTREPR: Percentage of directors with experience 19 PROFESSIONAL EXPERIENCE ENTREPRENEUR: dummy variable as an entrepreneur equal to one for directors with a previous professional experience as entrepreneur and zero otherwise

$20 \%$ OTHER EXP: Percentage of directors with other 20 OTHER PROFESSIONAL EXPERIENCE: dummy variable equal to work experience one for directors with other previous professional experience and zero otherwise

INDEPENDENCE \& BALANCE OF POWERS

$21 \%$ EXECUTIVES: Percentage of executive directors

21 EXECUTIVE: dummy variable equal to one if the director is an executive director and zero otherwise

$22 \%$ INDEPENDENT: Percentage of independent 22 INDEPENDENT: dummy variable equal to one if the director is an directors independent director and zero otherwise

23 POWER CONCENTRATION: It is a measure of 23 COMMITTEES: dummy variable equal to one if the director seats in at concentration of power in the board It is computed as least one committee and zero otherwise $=1$ - (number of directors in committees /number of directors in the board) TIME COMMITMENT

24 PRESENCE: Average percentage of meetings attended 24 MEETINGS ATTENDED: percentage of meetings attended by the by directors director

25 OTHER OFFICES: Average number of other offices 25 OTHER OFFICES: number or other offices held held by the directors in other boards or supervisory bodies

\section{STRUCTURE}

26 CG MODEL: Corporate Governance model: One-tier, Two-tier, Other board governance model

27 N DIRECTORS: Number of directors

28 TURNOVER: Past turnover of members from 2010 to 2014

\subsection{Self-Organizing Maps (SOMs)}

The Self-Organizing Map (SOM) (Kohonen, 1982, 1997) is a computational model extending the intuition of Willshaw and von der Malsburg (1976, 1979), who discovered that some areas of the brain develop specialized structures in different areas with high sensitivity for a specific input pattern.

From a technical viewpoint, the SOM looks like a grid (rectangular or hexagonal), with each point representing a neuron. This plane, and the nodes in it, is driven through a learning procedure to mimic in a bi-dimensional space the organization of the $n$-dimensions input space (with $n$ sensitively greater than 2 ). The underlying algorithm hence performs both classification and dimensionality reduction and has been used extensively in various Economics and Management fields of research, as testified by a huge literature corpus (Kolari \& Sanz, 2017; Mints, 2019; Dameri, Garelli, \& Resta, 2020). However, so far, SOMs have rarely been applied in the corporate governance literature (Somers \& Casal, 2017).

Nevertheless, using SOMs could help to improve knowledge of the similarity among banks' boards of directors, not only by grouping banks into clusters but also by going deep to the root of those groups' configuration.

Concerning our database, we first group banks according to specific criteria or dimensions relating to their management bodies. In this respect, the SOM can be thought of as a processing unit that acquires information from a multidimensional space and organizes it into a projection on a bi-dimensional plane. Moreover, the SOM conciliates and supersedes the known limitations of other dimension-reduction and clustering techniques such as Principal Component Analysis (PCA) (Pearson, 1901; Yeung \& Ruzzo, 2001; Gorban, Kegl, Wunsch, \& Zinovyev, 2007), and k-means clustering (k-means) (Hartigan \& Wang, 1979; Ding \& He, 2004; Lee \& Megrey, 2010; Toor \& Singh, 2013).

Perhaps the most notable features of SOMs can be summarized as two capabilities: (i) extracting the main features of the data without any explicit analytic formula to explain dependencies among the variables; (ii) 
extensive visualization of the banks' position on the plane.

The first capability can be explained with an example focusing on the dimensions of our database, a set of 40 banks characterized by 28 variables. Following a conventional econometric approach, the position of the banks depends on how all 28 variables interact through a (not known) non-linear function that must be estimated; in our approach, on the other hand, we do not care about this function because the final positioning of the bank is the result of how neurons organize themselves through the learning procedure (see Appendix A) based on a similarity function which, incidentally, is known and far easier to manage than a generic function in 28 variables.

The second capability relies on the extensive visualization features of SOMs. SOMs can, in fact, be represented as a 2-D projection plane with units (the neurons) arranged in either a rectangular or hexagonal shape, as shown in Figure 1.

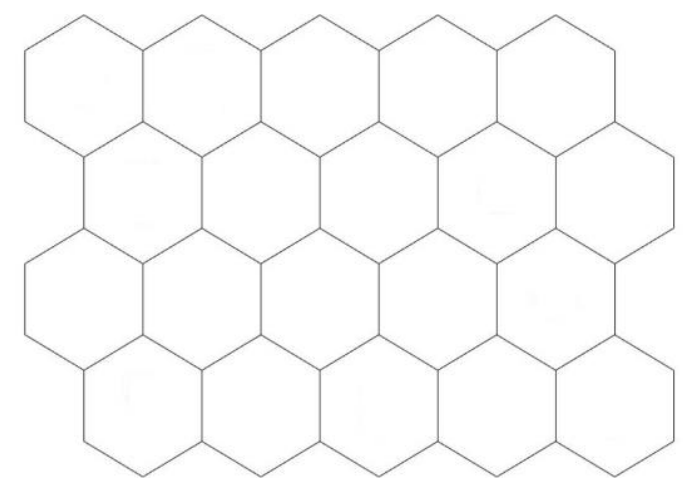

Figure 1. A SOM with a rectangular shape

Source: authors' elaboration.

Moreover, SOMs offer a platform for further visual investigation in three directions. First, the direct output of the SOM procedure is the so-called U-Matrix. In summary, the U-Matrix nodes (hexagons) are colored according to their distance from one another (see Figure 2). On the one hand, a dark coloring between the neurons also corresponds to a large distance between codebooks in the input space; on the other hand, a light coloring between the neurons means that the vectors are close to one another in the input space. Light-colored areas can be thought of as clusters and dark areas as cluster separators; however, this holds especially in the case of well-defined input features, as in the case of customer segmentation (Hanafizadeh \& Mirzazadeh, 2011). Nevertheless, as in our case, the original situation may be more blurred, as our variables are picked from five profiles of collective suitability and are very pointed. The consequence is that the U-Matrix represents an intermediate step, and it is necessary to perform additional k-means analysis to identify unambiguous clusters.
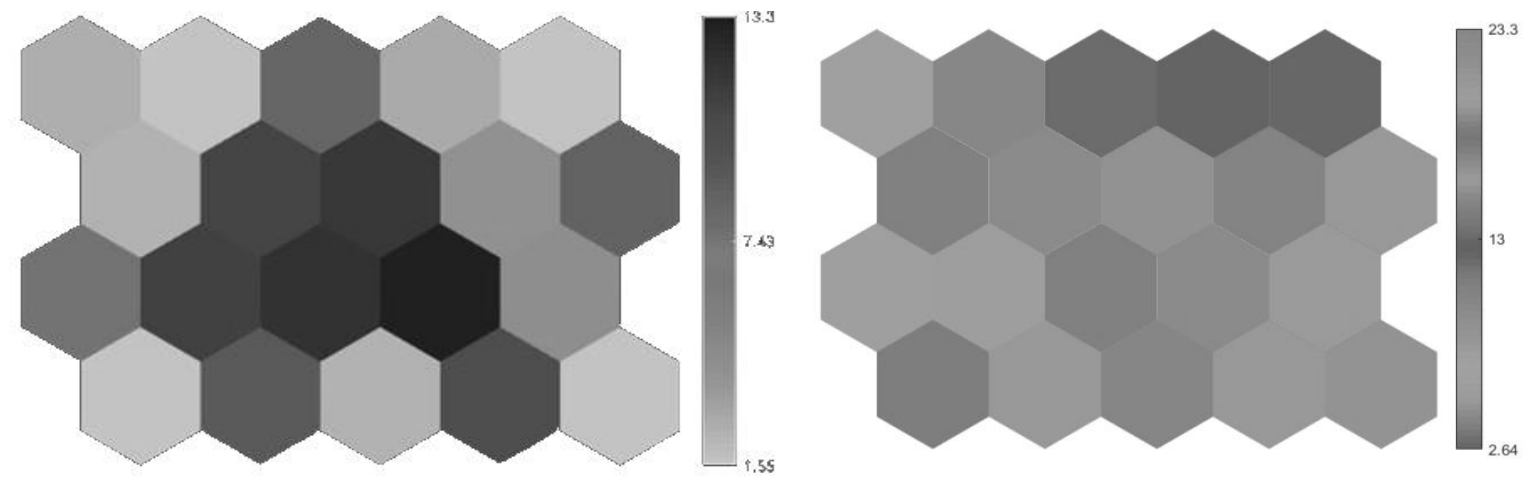

Figure 2. Examples of U-Matrix

Source. authors' elaboration.

In this way, blurs can be replaced by distinct colors corresponding to separate archetypes whose features can then be investigated with the aid of more conventional statistical analytic tools. 
Second, the contribution of each variable can be interpreted employing the Components Maps (CMs). CM can be thought of as a sliced version of the SOM, that allows to visualize the distribution of the input data in relation to the component under examination: in this case, we have, therefore, $28 \mathrm{CMs}$. The analysis of the CMs also provides hints on the correlation of a pair of components as a measure of the strength of their relation. CMs are generally reported represented in full colors, while the U-Matrix is in grayscale. CMs colors are read according to these rules: for input data, if nodes have the same or similar color, input vectors have similar behavior. Additionally, in the CMs, areas with similar colors in two maps suggest the existence of a positive correlation between variables; while when similar areas are associated with different colors, input variables are negatively correlated.

The results of the CMs can be also appreciated by deriving a "DNA matrix". The latter is a colored matrix whose rows (in our case, the banks) are colored according to the relevant color in the CMs (Note 5). The same color guidance described above applies. In this way, it is possible to obtain an overall representation of the "DNA features" of each bank without giving up the simplicity of the 2-D visualization offered by the SOM (Resta, 2022).

\subsection{Panel Regressions}

After grouping the banks within each archetype, we perform a panel analysis to test for the impact of the combination of the different features and the degree of collective suitability of each archetype on: i) financial and market performance; ii) banks' riskiness; and iii) risk-adjusted performance (Table 3). To proxy financial and market performance, we use three different measures (return on average assets, ROA; return on average equity, ROE; and stock returns, $r$ i $)$, following the traditional empirical approach in banking and governance studies (e.g., Arnaboldi et al., 2018; Bøhren \& Strøm, 2010; Minton, Taillard, \& Williamson, 2014). Then, we use three measures of risk: risk-weighted assets to total assets (RWA/TA) to measure the overall exposure to risks; non-performing loans to gross loans (NPL/GL) as a proxy of credit risk; and the standard deviation of stock returns (sd_i) to capture the market perception of a bank's riskiness. Finally, we also use risk-adjusted performance measures to capture a bank's ability to remunerate risks adequately. The first measure we use is the return on risk-weighted assets, computed as the ratio between net income and risk-weighted assets (RoRWA); second, we use the ratio between net income and total regulatory capital (RoTRC); finally, in a stock market perspective, we also use the annualized stock returns over the annualized standard deviation of returns $\left(\mathrm{r} \_\mathrm{i} / \mathrm{sd} \_\mathrm{i}\right)$.

We model performance, risk, and risk-adjusted performance as the outcome of the combination of board features (i.e., the board archetype within which each bank is grouped), which is our explanatory variable of interest, and a set of control variables, according to the following relation:

$$
\operatorname{perf}_{i, t}=f\left(\operatorname{Arc}_{i} ; X_{i, t} ; Y_{i, t}\right)=\alpha+\beta A \operatorname{Arc}_{i}+\gamma^{\prime} X_{i, t}+\delta^{\prime} Y_{i, t}+\varepsilon_{i, t}
$$

where (Table 3):

- $\quad \operatorname{Perf}_{\mathrm{i}, \mathrm{t}}$ is the dependent variable for bank $i$ at time $t$;

- $\quad \operatorname{Arc}_{\mathrm{i}}$, is a categorical variable with $\mathrm{n}$ levels, each representing the $\mathrm{n}$ board governance archetypes obtained using the SOM operationalized on the features of boards in charge at the end of 2014. In the regression, this variable is transformed into $n-1$ dummy variables, each taking the value of 1 when a bank is part of the specific archetype and 0 otherwise. Board archetype dummies are used as synthetic indicators of the overall features of the bank's board;

- $\quad \mathrm{X}_{\mathrm{i}, \mathrm{t}}$ is a set of firm characteristics at time $t$ for bank $i$ including: size, proxied by the natural logarithm of total assets and its squared value to catch any non-linearity in the relationship; and business model, proxied by the ratio of deposits to total assets (DEP/TA) and the weight of gross loans to total assets (GL/TA). When measuring performance with ROE, we also control for capitalization, measured by equity to total assets (E/TA);

- $\quad \mathrm{Y}_{\mathrm{i}, \mathrm{t}}$ includes control variables describing the economic and market conditions of the country where the bank $i$ is headquartered at time $t$, including GDP growth (GDP_g) and the interest rate level, proxied by the interest rate on long-term sovereign debt (y10bond). In a further specification of the model, we control for countries experiencing a severe banking crisis in the years following the start of the financial crisis (i.e., Italy, Spain, Portugal, and Ireland - ISPI). When the dependent variable is a stock market measure, we also control for domestic stock market returns (r_mkt);

- $\quad \alpha, \beta, \gamma$, and $\delta$ are the coefficients;

- $\varepsilon$ is the robust error. 
We run a panel regression with random effects and robust standard errors on our sample for the period 20142016. The dummy Arc refers to 2014, and it is time-invariant (Note 6); all the other variables refer to the three-year period ending in 2016. More explicitly, we test the effect of board governance overall features as of the end of 2014 - proxied by the bank's board archetype — on performance over the same year and the following two years, following a well-established approach (Beltratti \& Stulz, 2012; Grove et al., 2011; Sun \& Cahan, 2009) and allowing board decisions more time to produce their effects on performance. Moreover, introducing a time lag between the "Arc" variables, on the one hand, and performance and control variables, on the other, is useful in addressing the possible endogeneity issues - and more precisely, reverse causality - that may arise when exploring the relationship between board structure and performance.

Endogeneity often affects the governance-performance relationship: simultaneity or reverse causality (governance might be determined simultaneously with performance); unobserved heterogeneity (both governance and performance are driven by a third unobservable factor); and dynamic endogeneity (past performance shapes the current governance setting and also the current performance) (Hermalin \& Weisbach, 2003; Schultz et al., 2010). In line with previous studies (Arnaboldi et al., 2018; Sheikh, Shah, \& Akbar, 2018), we include in the regressions bank-specific controls (e.g., size and business model proxies) and country features (i.e., macroeconomic and market conditions) to account for any unobserved firm- and country-specific characteristics that could influence the relationship between performance and governance (Note 7).

Table 3. List of variables for the analysis of the performance-governance relationship

\begin{tabular}{|c|c|}
\hline Variable name & Variable definition \\
\hline \multicolumn{2}{|c|}{ DEPENDENT VARIABLES (Perf) } \\
\hline \multicolumn{2}{|l|}{ Return } \\
\hline ROA & Return on average assets \\
\hline ROE & Return on average equity \\
\hline r_i & Annualized stock return of bank $i$ \\
\hline \multicolumn{2}{|l|}{ Risk } \\
\hline RWA/TA & Risk weighted assets/total assets \\
\hline NPL/GL & Non-performing loans/gross loans \\
\hline sd_i & Annualized standard deviation of stock returns for bank $i$ \\
\hline \multicolumn{2}{|c|}{ Risk-adjusted performance } \\
\hline RoRWA & Return on risk weighted assets (net income/RWAs) \\
\hline RoTRC & Return on total regulatory capital (net income/TRC) \\
\hline r_i/sd_i & Annualized returns over annualized standard deviation for bank $i$ \\
\hline \multicolumn{2}{|c|}{ EXPLANATORY VARIABLES } \\
\hline Arc1 & A dummy variable equal to 1 if the bank pertains to Archetype 1 and 0 otherwise \\
\hline Arc 2 & A dummy variable equal to 1 if the bank pertains to Archetype 2 and 0 otherwise \\
\hline $\operatorname{Arc} 3$ & A dummy variable equal to 1 if the bank pertains to Archetype 3 and 0 otherwise \\
\hline Arc 4 & A dummy variable equal to 1 if the bank pertains to Archetype 4 and 0 otherwise \\
\hline \multicolumn{2}{|c|}{ CONTROL VARIABLES AND OTHER VARIABLES } \\
\hline Size & Natural log of total assets \\
\hline $\operatorname{Size}^{\wedge} 2$ & (Natural log of total assets) squared \\
\hline GL/TA & Gross Loans/total assets \\
\hline DEP/TA & Deposits and short-term funding/total assets \\
\hline E/TA & Equity/total assets \\
\hline GDP_g & GDP growth rate \\
\hline y10bond & Yield on 10-year maturity government bond \\
\hline r_mkt & Annualized index returns of the domestic stock market of bank $i$ \\
\hline ISPI & Dummy for banks headquartered in Italy, Spain, Portugal, Ireland \\
\hline
\end{tabular}

\section{Results}

\subsection{Board Archetypes and SOMs}

From an operative viewpoint, when running the SOM algorithm on our dataset, we examined various grid dimensions, choosing the best one with respect to the Quantization Error (QE) index values (Note 8). We therefore describe and discuss the results obtained by training a $4 \times 5$ map with a rectangular topology, reaching a 
QE of 0.00316 (very close to zero).

As already anticipated, to enhance the knowledge discovery process, the detection of clusters at the end of the learning procedure may require running an incremental k-means clustering procedure, stopping once the lowest average distance between clusters (less within-group distance between data points in the cluster) is reached. The ending point of the procedure is chosen according to the elbow point criterion, as shown in Figure 3: if one plots the percentage of variance explained by the clusters against the number of clusters, the first clusters will add considerable information (explain a lot of variance), but at some point, the marginal gain will drop, giving an angle to the graph. The number of clusters is chosen at this point, hence the "elbow criterion."

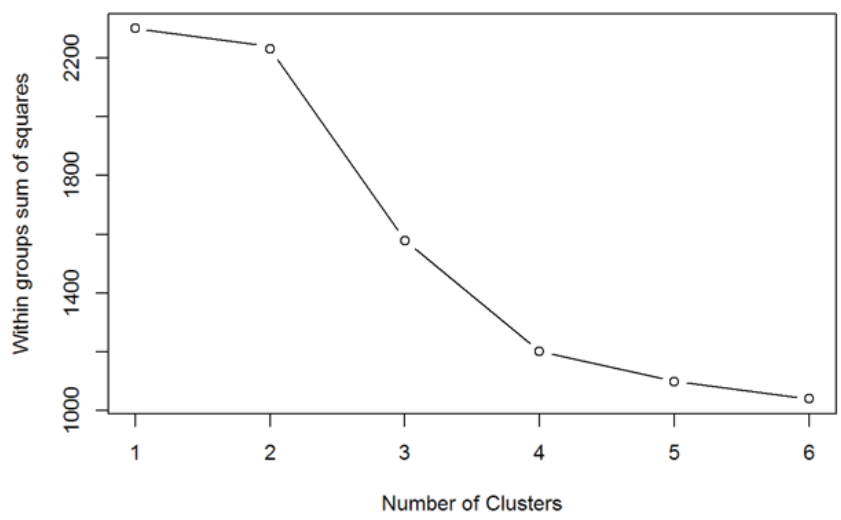

Figure 3. Elbow criterion to define the number of clusters

In Figure 3, the number of clusters is on the horizontal axis, and the value of the average distance within clusters is given on the vertical axis: the elbow point corresponds to an overall number of four clusters, and we divided the SOMs accordingly, as illustrated in Figure 4; hexagons represent the neurons, and the colors associated with the clusters represent the distances between neurons. The resulting matrix can be interpreted as a kind of U-Matrix adjusted with respect to intra/extra group measures. The colors subsequently aim to identify whether the nodes are similar to one another (and hence grouped together) or not (and hence put into different groups).

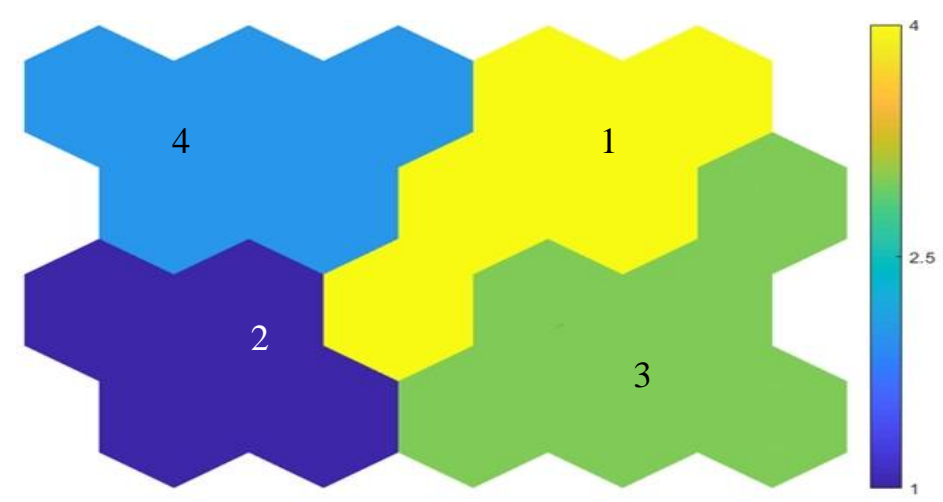

Figure 4. Board archetypes in the SOM

We explored the features of the board "model" adopted by each cluster by using two types of analyses: a visual analysis based on the DNA matrix (see Figure 5) and a more traditional investigation based on the descriptive statistics of each cluster (i.e., archetype) (Table 4). These tools offer complementary information, working back and forth between input and neural space. The DNA matrix, on the one hand, works in the neural space and visualizes how close representative neurons (i.e., the neurons mapping banks) are to one another; this, in turn, may help in understanding the closeness of the banks mapped therein. The descriptive statistics, on the other hand, examine the concept of similarity in the input space: banks clusters obtained by running the SOMs are now explored to analyze how close the banks are one to another in the cluster from the statistical viewpoint. 
Table 4. Sample means for the full sample and the four Archetypes

\begin{tabular}{|c|c|c|c|c|c|c|}
\hline & & chetype & & & & \\
\hline & PROFILE & 1 & 2 & 3 & 4 & FULL SAMPLE \\
\hline \multicolumn{7}{|c|}{ COMPETENCE } \\
\hline 1 & $\%$ DEGREE & 98.9 & 79.2 & 95.2 & 94.2 & 91.7 \\
\hline 2 & $\%$ POST DEGREE & 40.7 & 36.4 & 37.7 & 32.6 & 36.8 \\
\hline 3 & $\%$ FOREIGN STUDIES & 23.7 & 24.6 & 20.9 & 16.9 & 21.5 \\
\hline 4 & B\&F SCORE & 1.992 & 2.137 & 1.486 & 1.698 & 1.798 \\
\hline 5 & $\%$ BANK EXPERIENCE & 94.4 & 99.5 & 87.8 & 92 & 93 \\
\hline 6 & $\%$ SAME BANK EXPERIENCE & 6.3 & 91.2 & 12.5 & 30.6 & 35 \\
\hline 7 & $\%$ INTERNAT EXP & 47.6 & 45.4 & 35.3 & 40.9 & 41.6 \\
\hline$\underline{8}$ & $\%$ BOARD EXPERIENCE & 95 & 93.1 & 93.3 & 94.5 & 93.8 \\
\hline \multicolumn{7}{|c|}{ DIVERSITY } \\
\hline 9 & $\%$ WOMEN & 25.9 & 24.2 & 20.2 & 20.3 & 22.4 \\
\hline \multirow[t]{2}{*}{10} & $\%$ FOREIGN & 21.5 & 31.2 & 11.7 & 15.9 & 19.5 \\
\hline & Average AGE & 59.85 & 57.03 & 60.85 & 57.14 & 58.86 \\
\hline \multirow[t]{6}{*}{11} & CV Age & 0.046 & 0.057 & 0.045 & 0.051 & 0.057 \\
\hline & Education & & & & & \\
\hline & $\%$ BUSINESS \& ECO & 43.9 & 53.6 & 52.9 & 55.5 & 51.9 \\
\hline & $\%$ LAW & 24.6 & 12.4 & 19.4 & 23.2 & 19.5 \\
\hline & $\%$ STEM & 16.5 & 8.7 & 15.9 & 7.1 & 12.3 \\
\hline & $\%$ OTHER degree & 13.9 & 4.5 & 7 & 8.3 & 8 \\
\hline \multirow[t]{7}{*}{12} & BLAU-education & 0.70 & 0.69 & 0.65 & 0.63 & 0.67 \\
\hline & Professional experience & & & & & \\
\hline & $\%$ ACADEMICS & 7.5 & 1.8 & 14.8 & 10.9 & 9.2 \\
\hline & $\%$ CONSULT & 25.2 & 7.7 & 23.3 & 22.4 & 19.6 \\
\hline & $\%$ MANAGER & 11.6 & 85.3 & 18.7 & 42.3 & 39.2 \\
\hline & $\%$ ENTREPR & 8 & 0 & 13 & 0.5 & 5.9 \\
\hline & $\%$ OTHER experience & 47 & 5.2 & 30.3 & 23.2 & 25.8 \\
\hline \multirow[t]{2}{*}{13} & BLAU-professional exp & 0.69 & 0.26 & 0.78 & 0.71 & 0.73 \\
\hline & \multicolumn{6}{|c|}{ INDEPENDENCE \& BALANCE OF POWERS } \\
\hline 14 & $\%$ EXECUTIVE & 21.1 & 18.3 & 21.4 & 24.0 & 21.1 \\
\hline 15 & $\%$ INDEPENDENT & 61.6 & 44.8 & 47.6 & 47.3 & 49.8 \\
\hline \multirow[t]{2}{*}{16} & POWER CONCENTRATION & 24.1 & 28.4 & 28.3 & 25.1 & 26.8 \\
\hline & \multicolumn{6}{|c|}{ TIME COMMITMENT } \\
\hline 17 & PRESENCE AT MEETING (\%) & 96.5 & 95.99 & 95.56 & 91.45 & 95.06 \\
\hline \multirow[t]{7}{*}{18} & OTHER OFFICES & 2.88 & 3.88 & 4.6 & 1.92 & 3.47 \\
\hline & \multicolumn{6}{|c|}{ STRUCTURE } \\
\hline & CG MODEL prevailing & One-tier & One-tier & One-tier or other & Two-tier & One-tier \\
\hline & Number of Directors & 15 & 13 & 21.15 & 20.56 & 17.75 \\
\hline & TURNOVER & 44.1 & 53.4 & 53.6 & 56.7 & 52.4 \\
\hline & Size (Total assets in th Euros) & $8,348,486$ & $2,978,956$ & $6,546,855$ & $4,973,841$ & $22,848,138$ \\
\hline & $\mathrm{N}$ of banks & 8 & 10 & 13 & 9 & 40 \\
\hline
\end{tabular}

Note. In this table we find a subset of the variables illustrated in Table 2 plus the following variables (in Italics): CV Age: the coefficient of variation of age (computed as the standard deviation of directors age of each board divided by the average age of the board); for the degree, BLAU-Degree: the Blau Index for the various categories of degree; BLAU-Professional Exp: the Blau Index for the different categories of professional background The Blau Index is computed as $\boldsymbol{B}=\mathbf{1}-\sum_{i=\mathbf{1}}^{k} \boldsymbol{p}_{\boldsymbol{i}}{ }^{2}$, where $\mathrm{p}$ is the percentage of directors in a given category, and $\mathrm{k}$ is the total number of categories It varies between zero and its maximum (k-1/k) In the case of educational diversity, the maximum value for the Blau is 0.75 (four categories) and in the case of professional background it is 0.8 (five categories). 
governance features

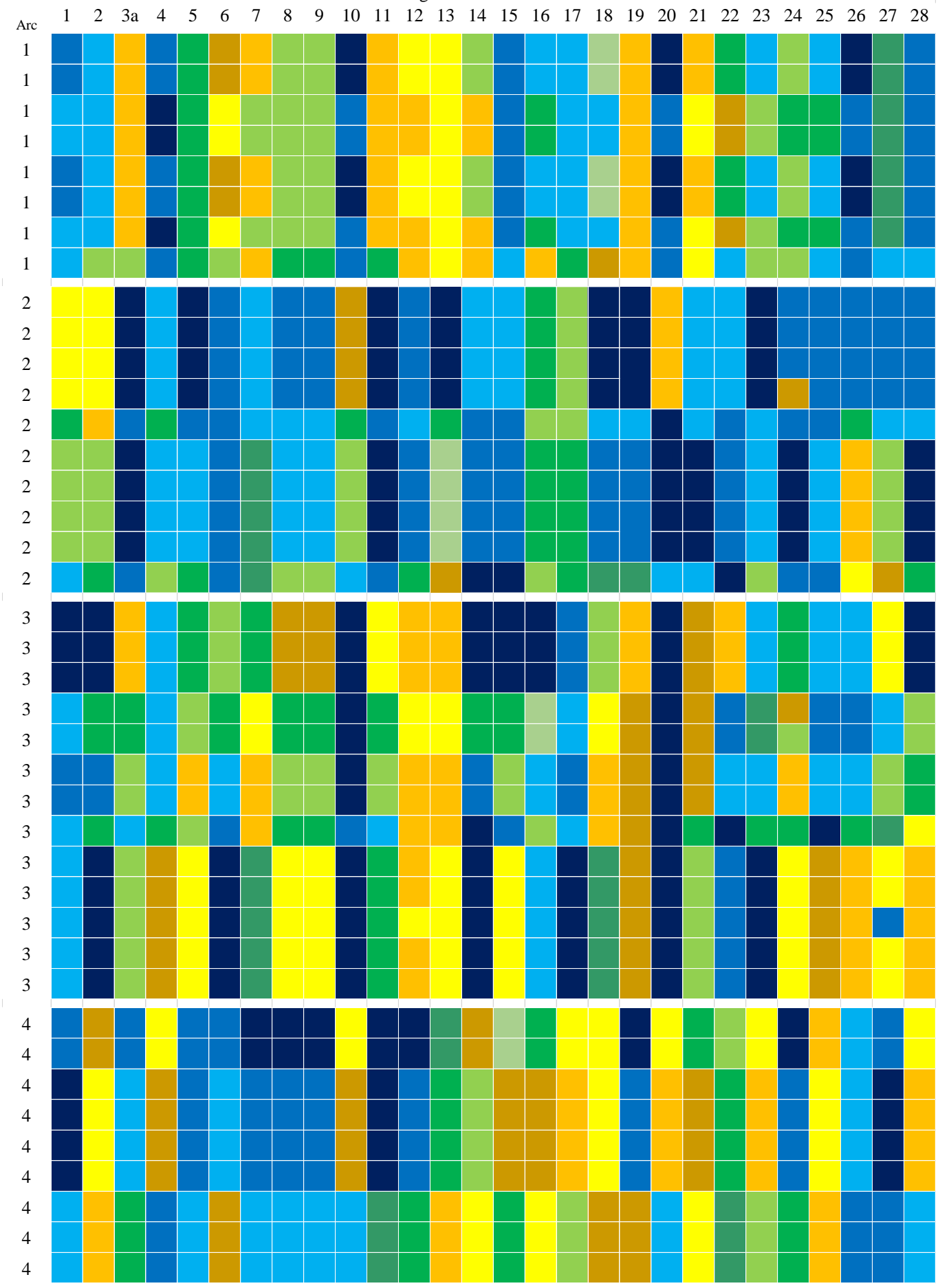

Figure 5. "DNA matrix"

Note. In the figure, each row represents a bank and banks are grouped according to their Archetype. Each column represents one of the 28 board governance features illustrated in Table 2, with the exception of 3a) that is the average age of directors, instead of the coefficient of variation of age. The cells are colored depending on the color associated with each variable in the component maps. Low values are in blue and green, higher values are colored in yellow tones.

Multiple reading keys are suggested by the DNA matrix. A preliminary observation reveals that the banks have been ordered according to the archetype to which they belong, that is, rows $1-8$ collect banks in the first archetype; rows 9-18 gather banks in the second archetype; and rows 19-31 and 32-40 group banks in the third and fourth archetypes, respectively. 
By rows, we can search for banks sharing similar DNA, i.e., a similar sequence of colors, and hence similar patterns of behavior. Consider, for instance, banks in rows 1-8: looking at how colors alternate by row, we can conclude that the archetype groups very homogeneous banks under the profile of all the examined indicators except for the bank (the neuron) in row 8; the dissimilarity with respect to other banks in the given archetype determines the overall intra-group distance, which justifies the yellow coloring in Figure 5.

The DNA matrix organization by columns also shows how banks are correlated to the examined variable. A homogeneous color by column means that neurons behave in the same way with respect to the examined variable, and hence that the mapped banks will move toward the same direction; on the contrary, different column colors are associated with non-homogeneous (i.e., not toward the same direction) behavior.

\subsection{Board Archetypes Features and Collective Suitability}

We now outline the features of the four board archetypes, highlighting their proximity to the definition of collective suitability provided by the regulation.

Archetype\#1 (Arcl): boards in this group have few directors, that have - on average - strong and diverse educational backgrounds (e.g., they have the highest percentage of members with a university degree and a post-degree diploma). They also have B\&F score above sample average, and 94\% of them have worked previously in a financial institution and have also frequently worked abroad. Boards show a high degree of diversity in terms of gender, age, professional expertise, and geographical provenance of the directors. The percentage of independent is high, and boards have the lowest concentration of power among directors. Finally, the time commitment of directors is the highest, which is consistent with these board members holding a low number of other directorships.

Archetype\#2 (Arc2): these boards have the lowest number of directors, competencies are quite high and pertain specifically to the banking and financial sector. Almost all board members have professional experience in a financial institution in addition to extensive skills (board members on average have the highest levels of B\&F scores). Moreover, almost $90 \%$ of directors in this group have previously had a professional relationship with the same bank. The educational background is mainly in Economics, Management, and/or Accounting studies, though the percentage of directors with a university degree is the lowest among all the archetypes. On average, the board composition in this group is highly heterogeneous in terms of age, geographical provenance of directors, and gender, but less diverse in terms of previous professional experience due to the high percentage of bank managers. The percentage of executive directors is lowest in comparison to the other groups. Despite the higher number of other mandates/offices of directors, the time committed to the bank is slightly higher than the overall average. Power is more concentrated, probably since this Archetype shows the lowest percentage of independent directors, i.e., those who usually sit on board committees.

Archetype\#3 (Arc3): educational background shows higher scores than the sample and a good degree of diversification in the subjects of study. However, specific skills and competencies in banking and finance are rather low (i.e., the lowest B\&F score and previous experience in banking and finance), despite board members having a diversified professional background. Besides, $30 \%$ of them are professional independent directors, also consistent with the high average number of other mandates. Gender and nationality diversity is definitely lower, powers tend to be concentrated, despite the percentage of independent directors being above the sample average. Finally, the average number of board members is the largest in our sample, and their age is the highest.

Archetype\#4 (Arc4): boards have a high number of directors (like Arc3) - probably due to the prevalence of a two-tier governance model - but scarcely diversified in terms of gender and nationality and with a higher percentage of executives and/or non-independent directors. The participation in board meetings is the lowest, despite directors holding fewer other offices. The educational background is concentrated in Economics and/or Management, though a significant proportion has a degree in Law, and only a very small proportion have postgraduate degrees or have studied abroad. The professional background varies, although most members are or have been a manager, board director, or consultant/advisor. Competence in banking and finance is slightly lower than average, but a third of board members have working experience in the same institution.

We now rank the archetypes according to the following interpretation of the regulatory criteria (Figure 6).

- $\quad$ Competence: the higher the percentage of directors holding a specific competency or skill (e.g., previous bank experience) or level of a feature (e.g., B\&F score), the closer to the regulatory requirements.

- Diversity: the higher the level of diversity, the higher the level of suitability.

- Independence and balance of power: the lower the percentage of executives and the concentration of powers and the higher the presence of independent directors, the closer the board to the suitability rules. 
- $\quad$ Time commitment: the higher the presence at meetings and the lower the number of other offices held by directors, the higher the level of suitability.

We use the variables already used for the SOM (Table 4). However, to better proxy the degree of diversity within the board, instead of average age, we take the coefficient of variation of age ("CV Age"). Similarly, we substitute the percentage of directors who graduated in the different areas of study and with different types of professional experience, with the respective Blau Index: "Blau-education" and "Blau-professional exp" (Note 9).

Arc1 and Arc2 almost always appear in the top positions, showing higher compliance with the regulatory definition; hence, these can be assumed to be the closest to the collective suitability requirements. Arc 3 and $\operatorname{Arc} 4$ hold the last positions in most cases, showing lower levels of diversity and lower levels of competencies. These two clusters can, therefore, be considered to be farther away from the regulatory definition of collective suitability. The positioning is also confirmed by the median of the various values obtained by the groups. Archetype 1 (Arc1) has a median position of 1.5, Arc2 of 2, whereas Arc3 and Arc4 both score 3.0 as median position.

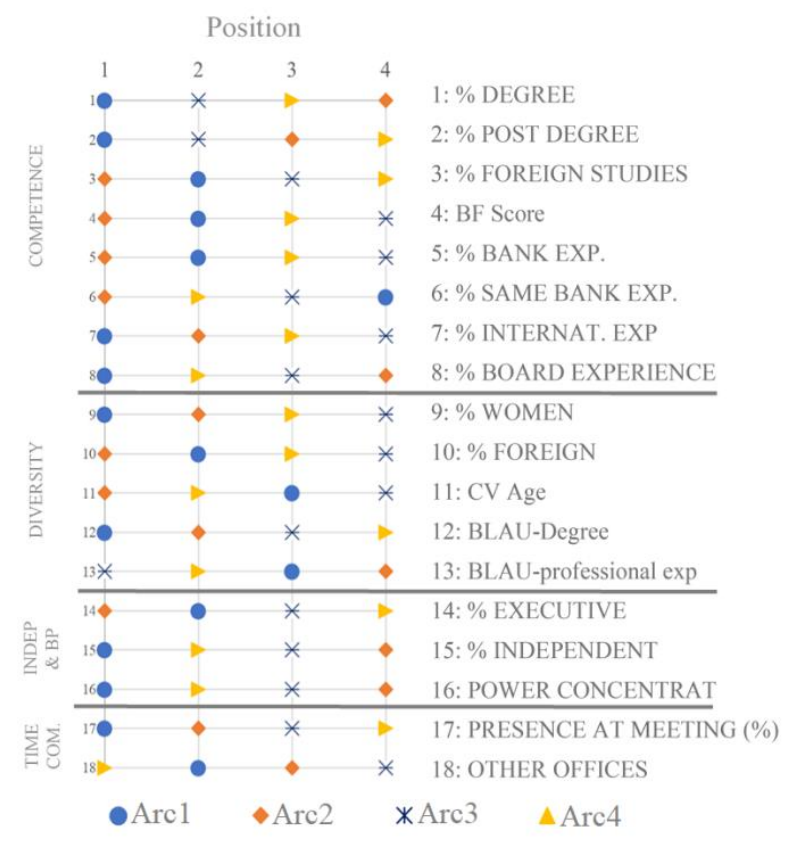

Figure 6. Ranking of the four archetypes

Note. The horizontal lines divide the features used to describe competence, diversity, independence and balance of power (indep \& BP) and time commitment (time com); 1 indicates the best position in the ranking and 4 the lowest.

\subsection{Board Collective Suitability and Bank Performance}

At this stage, we run panel regressions to shed more light on the relationship between board archetypes and performance, risk, and risk-adjusted performance. Better governance (in accordance with the definition of the CRD4) should be able to control and monitor management, thus yielding better performance and risk management for the bank, or in general produce value creation. Below are summarized the results for our dependent variables.

a. performance: results for ROA and ROE (Table 5-Panel A) show that board archetypes influence bank performance. Coefficients of the dummies Arc1 and Arc2, i.e., the groups of banks with boards closer to the collective suitability paradigm, have a positive sign and are statistically significant. This confirms that board quality and, more precisely, its degree of collective suitability have a positive influence on the management of the bank, ultimately resulting in better performance. To give a rough idea of the effect of good board governance, for banks in Arc1, i.e., the better-positioned cluster in the overall ranking, ROA and ROE are $0.7-0.8 \%$ and 8.69.4\% higher, respectively, than those of banks in Arc4, which is taken as the benchmark for the analyses.

When controlling for bank-specific variables, we find a negative sign for GL/TA, suggesting that traditional credit intermediaries achieve poorer performance, in line with Bongini et al. (2019), Ayadi et al. (2020), Farnè 
and Vouldis (2020). Among country-specific variables, we find a negative relationship between performance and sovereign interest rates (y10bond): higher spreads not only increase the cost of bank funding but also proxy for the country's poor macroeconomic fundamentals, which also decreases bank profitability. Finally, banks located in countries experiencing severe banking crises (ISPI) achieve worse performances, thus confirming the systematic nature of the domestic banking sector (Fiordelisi \& Marques-Ibanez, 2013).

Market performance provides similar results for Arc1 thus hinting that shareholders' prize the overall composition and competence of the board. Not surprisingly, bank stock returns are mainly influenced by market returns and are less affected by other bank-specific features (Note 10).

The significance of the models appears quite high, with linear regressions explaining around $25-31 \%$ of the data. Additionally, the chi-squared statistics confirm the validity of the overall models.

Table 5. Results of the panel regressions Sample period 2014-2016

Panel A: Financial and market performance

\begin{tabular}{|c|c|c|c|c|c|c|c|c|c|c|c|c|}
\hline \multirow{2}{*}{$\begin{array}{l}\text { Variable } \\
\text { Arc1 }\end{array}$} & \multicolumn{4}{|c|}{ ROA } & \multicolumn{4}{|c|}{ ROE } & \multicolumn{4}{|c|}{$\mathrm{r} \_\mathrm{i}$} \\
\hline & 0.744 & $* * *$ & 0.756 & $* * *$ & 8.626 & $*$ & 9.436 & $*$ & 29.765 & & 34.670 & $*$ \\
\hline Arc2 & 0.658 & $* * *$ & 0.653 & $* * *$ & 13.672 & $* * *$ & 12.143 & $* * *$ & 27.834 & & 23.128 & \\
\hline Arc3 & 0.204 & & 0.217 & & 5.764 & & 7.437 & & 20.516 & & 25.866 & \\
\hline Size & 3.798 & & 3.742 & & 36.037 & & 26.294 & & 55.122 & & 34.012 & \\
\hline $\mathrm{Size}^{\wedge} 2$ & -0.103 & $*$ & -0.101 & & -0.950 & & -0.702 & & -1.420 & & -0.915 & \\
\hline GL/TA & -0.020 & $* *$ & -1.930 & $* *$ & -0.301 & $*$ & -0.149 & & -0.473 & & -0.072 & \\
\hline DEP/TA & 0.005 & & 0.489 & & -0.028 & & -0.023 & & 0.157 & & 0.225 & \\
\hline E/TA & & & & & 2.553 & & 3.244 & $*$ & & & & \\
\hline GDP_g & -0.012 & & -0.012 & & -0.390 & $*$ & -0.310 & & -4.143 & $* *$ & -3.742 & $* *$ \\
\hline y10bond & -0.157 & $* *$ & -0.150 & $*$ & -3.911 & $* *$ & -2.391 & & 3.106 & & 7.963 & $*$ \\
\hline ISPI & & & -0.060 & & & & -10.397 & $* * *$ & & & -27.788 & $*$ \\
\hline r_mkt & & & & & & & & & 2.132 & $* * *$ & 2.070 & $* * *$ \\
\hline Constant & -33.829 & & -33.301 & & -334.698 & & -250.954 & & -544.373 & & -349.273 & \\
\hline Number of banks & 40 & & 40 & & 40 & & 40 & & 40 & & 40 & \\
\hline $\mathrm{R} 2$ overall & 0.253 & & 0.253 & & 0.283 & & 0.312 & & 0.260 & & 0.284 & \\
\hline Chi-2 & 31.764 & & 31.804 & & 22.598 & & 26.817 & & 35.019 & & 39.058 & \\
\hline $\mathrm{P}$-value & 0.000 & & 0.000 & & 0.012 & & 0.005 & & 0.000 & & 0.000 & \\
\hline
\end{tabular}

Panel B: Risk

\begin{tabular}{|c|c|c|c|c|c|c|c|c|c|c|c|c|}
\hline \multirow{2}{*}{$\begin{array}{l}\text { Variable } \\
\text { Arc1 }\end{array}$} & \multicolumn{4}{|c|}{ RWA/TA } & \multicolumn{4}{|c|}{ NPL/GL } & \multicolumn{4}{|c|}{ sd_i } \\
\hline & 7.575 & & 4.781 & & -5.673 & $*$ & -7.846 & $* *$ & -10.409 & $*$ & -10.280 & $*$ \\
\hline Arc2 & -8.767 & $*$ & -8.238 & $*$ & -6.819 & $*$ & -6.219 & $* *$ & 4.421 & & 1.985 & \\
\hline Arc3 & 2.961 & & 0.337 & & 1.474 & & -0.639 & & -6.995 & & -6.390 & \\
\hline Size & -102.024 & $* * *$ & -98.352 & $* *$ & -46.896 & $* *$ & -44.082 & $* * *$ & 6.201 & & -1.111 & \\
\hline $\mathrm{Size}^{\wedge} 2$ & 2.511 & $* *$ & 2.452 & $* *$ & 1.215 & $* *$ & 1.169 & $* * *$ & -0.158 & & 0.031 & \\
\hline GL/TA & 0.343 & $* *$ & 0.271 & & 0.236 & $* * *$ & 0.202 & $* * *$ & 0.025 & & 0.094 & \\
\hline DEP/TA & -0.035 & & -0.036 & & -0.013 & & -0.032 & & 0.001 & & -0.038 & \\
\hline GDP_g & 0.069 & & 0.045 & & -0.044 & & -0.056 & $* *$ & 0.463 & & 1.102 & $* *$ \\
\hline y10bond & 1.602 & $* * *$ & 1.343 & $* *$ & 0.926 & $* * *$ & 0.781 & $* * *$ & 5.337 & $* *$ & 8.396 & $*$ \\
\hline sd_mkt & & & & & & & & & 2.196 & $* *$ & 2.617 & $* * *$ \\
\hline ISPI & & & 9.183 & $*$ & & & 7.076 & $* *$ & & & -7.589 & \\
\hline Constant & 1050.082 & $* * *$ & 1002.700 & $* * *$ & 446.763 & $* *$ & 410.340 & $* *$ & -73.585 & & -15.926 & \\
\hline Number of banks & 39 & & 39 & & 39 & & 39 & & 40 & & 40 & \\
\hline R2 overall & 0.506 & & 0.580 & & 0.540 & & 0.610 & & 0.356 & & 0.381 & \\
\hline Chi-2 & 92.683 & & 121.240 & & 80.889 & & 131.113 & & 96.799 & & 139.434 & \\
\hline P-value & 0.000 & & 0.000 & & 0.000 & & 0.000 & & 0.000 & & 0.000 & \\
\hline
\end{tabular}


Panel C: Risk-adjusted performance

\begin{tabular}{|c|c|c|c|c|c|c|c|c|c|}
\hline \multirow{2}{*}{$\begin{array}{l}\text { Variable } \\
\text { Arc1 }\end{array}$} & \multicolumn{3}{|c|}{ RoRWA } & \multicolumn{3}{|c|}{ RoTRC } & \multicolumn{3}{|c|}{ r_i $\mathrm{i} / \mathrm{sd} \_\mathrm{i}$} \\
\hline & 1.678 & $* * *$ & $1.858 * * *$ & $12.444 * * *$ & $13.113 * * *$ & 0.549 & $*$ & 0.573 & \\
\hline $\operatorname{Arc} 2$ & 2.094 & $* * *$ & $1.975 * * *$ & $13.040 * * *$ & $12.537 * * *$ & 0.313 & & 0.308 & \\
\hline Arc3 & 0.545 & & 0.715 & 5.030 & 5.673 & 0.525 & & 0.536 & \\
\hline Size & 10.285 & $*$ & 9.564 & 45.937 & 42.981 & 0.669 & & 0.665 & \\
\hline $\operatorname{Size}^{\wedge} 2$ & -0.273 & $*$ & $-0.256 *$ & -1.248 & -1.178 & -0.017 & & -0.017 & \\
\hline GL/TA & -0.040 & $*$ & -0.028 & $-0.332 *$ & -0.286 & 0.011 & & 0.012 & \\
\hline DEP/TA & 0.001 & & 0.003 & 0.058 & 0.067 & -0.001 & & -0.000 & \\
\hline GDP_g & -0.052 & & -0.044 & -0.259 & -0.221 & -0.095 & $* * *$ & -0.091 & $* * *$ \\
\hline y10bond & -0.529 & $* *$ & $-0.418 *$ & $-2.646 *$ & -2.157 & -0.157 & & -0.091 & \\
\hline ISPI & & & -0.850 & & -3.329 & & & -0.195 & \\
\hline r_mkt & & & & & & 0.038 & $* * *$ & 0.039 & $* * *$ \\
\hline sd_mkt & & & & & & -0.055 & $* *$ & -0.044 & \\
\hline Constant & -93.400 & & -86.530 & -403.209 & -357.227 & -5.867 & & -6.232 & \\
\hline Number of banks & 40 & & 40 & 40 & 40 & 40 & & 40 & \\
\hline $\mathrm{R} 2$ overall & 0.317 & & 0.333 & 0.255 & 0.261 & 0.255 & & 0.253 & \\
\hline Chi-2 & 32.633 & & 33.780 & 33.571 & 34.057 & 75.896 & & 76.453 & \\
\hline P-value & 0.000 & & 0.000 & 0.000 & 0.000 & 0.000 & & 0.000 & \\
\hline
\end{tabular}

Note. *,**,*** indicate respectively 10,5 and $1 \%$ significance levels.

b. risk: results are less straightforward and vary depending on the proxy used (Table 5-Panel B). Arc1 and Arc2 show a negative and significant effect on credit risk (NPL/GL) suggesting that boards closer to collective suitability can manage and control risk better. Results are however less clear-cut when we look at overall bank riskiness, i.e., risk-weighted assets to total assets (RWA/TA). The control variables show signs that are consistent with the expected relationships. "Size" shows a negative sign, whereas "size ${ }^{2}$ " shows a positive sign: larger banks can diversify risk but that the marginal beneficial effect of diversification decreases after a certain threshold. As expected, risk is positively affected by gross loans (GL/TA) and y10bond. Finally, banks located in ISPI countries present a greater degree of risk. With reference to market risk, results confirm the negative coefficient for Arc1, although, results appear to be driven mainly by macroeconomic variables (sd_mkt and y10bond). Overall, mixed findings on risk may be consistent with two different hypotheses. The first assumes that the deposit guarantee scheme represents an incentive for the board to take on more risk in the interests of shareholders (Beltratti \& Stulz, 2012). The second assumes that poor-quality boards may not be able to control executives, who take fewer risks to protect their benefits.

c. risk-adjusted performance: Arc1 and Arc2 still have a positive and significant sign bot for RoRWA and RoTRC, hence achieving better performance per unit of risk (Table 5-Panel C). The same holds for the adjusted market-return, but only for Arc1 (Note 11). Macroeconomic variables confirm their expected signs, in line with the results for performance.

\subsubsection{Alternative Specifications}

To tackle potential endogeneity concerns, we perform two additional empirical analyses (Note 12). First, to address potential reverse causality issues, we introduce a further time lag and restrict the period of the panel analysis to 2015-2016 and hold the archetype dummies fixed at 2014. The overall results confirm that banks whose management bodies are more in line with the regulatory paradigm, i.e., Archetypes \#1 and \#2, enjoy better performance in terms of operating performance, risk management, and risk-adjusted performance.

Second, in line with Grove et al. (2011), we perform cross-sectional regressions using as a dependent variable the average performance for the years 2014-2016 or, alternatively, for the years 2015-2016, and independent and control variables constant as of the end of 2014. In this way, we reduce the time trend of the dependent variable, and we try to curb dynamic endogeneity (Beltratti \& Stulz, 2012). The results confirm that in most of the specifications tested, proximity to the board suitability paradigm provides the expected results (i.e., Arc1 and Arc2 have higher performance, higher risk-adjusted performance, and lower risk). The control variables, however, show lower statistical significance than in the panel regression.

\section{Conclusions}

Our study investigates the board governance features of a sample of 40 European banks and contributes to the empirical literature on the relationship between board characteristics and performance. We focus on the concept 
of collective suitability formalized by the CRD4, and, departing from previous contributions, we jointly analyze board features and how they combine with one another. For this purpose, we use SOMs, a machine learning methodology that is a relatively new approach in studies on governance and allows for a comprehensive and inductive analysis of board features. Additionally, we assess whether the proximity to the collective suitability regulatory paradigm affects bank performance, risk, and risk-adjusted performance measures.

As a first contribution, our study identifies four board archetypes characterized by different degrees of collective suitability. Among them, two archetypes (Arc1 and Arc2) are shown to be better positioned in terms of the collective suitability of the board with respect to most of the governance features we investigate, whereas the other two (Arc3 and Arc4) show worse positioning in general both in terms of diversity and competence, showing high overall distance from the collective suitability regulatory paradigm.

As a second contribution, we provide new evidence on the relationship between board archetypes and their degree of collective suitability and bank performance. Our results support the hypothesis that the degree of collective suitability of the board of directors positively affects bank economic and financial performance and risk-adjusted performance, and also, to a lesser extent, the ability to control risks.

Overall, our results represent, on the one hand, an incentive for banks to further improve their board attributes. On the other hand, they confirm that, despite the need for further refinement and harmonization, bank governance regulation has been going in the right direction, thereby enhancing prudent and effective management. Further research can help in overcoming the possible limitations of our study. It would be important to understand how the suitability of the board of directors will evolve over time, employing suitable techniques to cope with the empirical challenges described in this paper, and understand also how smaller banks can comply with the regulatory requirements on corporate governance, especially in attracting diverse and skilled directors.

\section{References}

Adams, R. B., Akyol, A. C., \& Verwijmeren, P. (2018). Director skill sets. Journal of Financial Economics, 130(3), 641-662. https://doi.org/10.1016/j.jfineco.2018.04.010

Adams, R. B., \& Ferreira, D. (2009). Women in the boardroom and their impact on governance and performance. Journal of Financial Economics, 94(2), 291-309. https://doi.org/10.1016/j.jfineco.2008.10.007

Aebi, V., Sabato, G., \& Schmid, M. (2012). Risk management, corporate governance, and bank performance in the financial crisis. Journal of Banking and Finance, 36(12), 3213-3226. https://doi.org/10.1016/j.jbankfin.2011.10.020

Altunbaş, Y., Thornton, J., \& Uymaz, Y. (2020). The effect of CEO power on bank risk: Do boards and institutional investors matter? Finance Research Letters, 33, 101202. https://doi.org/10.1016/j.frl.2019.05.020

Anginer, D., Demirguc-Kunt, A., Huizinga, H., \& Ma, K. (2018). Corporate governance of banks and financial stability. Journal of Financial Economics, 130, 327-346. https://doi.org/10.1016/j.jfineco.2018.06.011

Arnaboldi, F., Casu, B., Gallo, A., Kalotychou, E., \& Sarkisyan, A. (2021). Gender diversity and bank misconduct. Journal of Corporate Finance, 101834. https://doi.org/10.1016/j.jcorpfin.2020.101834

Arnaboldi, F., Casu, B., Kalotychou, E., \& Sarkisyan, A. (2018). The performance effects of board heterogeneity: what works for EU banks?. European Journal of Finance, 26(10), 897-924. https://doi.org/10.1080/1351847X.2018.1479719

Ayadi, R., Bongini, P., Casu, B., \& Cucinelli, D. (2020). Bank Business Model Migrations in Europe: Determinants and Effects. British Journal of Management, 1-20. https://doi.org/10.1111/1467-8551.12437

Basel Committee on Banking Supervision [BCBS]. (2015). Guidelines, Corporate governance principles for banks, July.

Beltratti, A., \& Stulz, R. M. (2012). The credit crisis around the globe: Why did some banks perform better? Journal of Financial Economics, 105(1), 1-17. https://doi.org/10.1016/j.jfineco.2011.12.005

Bennouri, M., Chtioui, T., Nagati, H., \& Nekhili, M. (2018). Female board directorship and firm performance: What really matters? Journal of Banking and Finance, 88, 267-291. https://doi.org/10.1016/j.jbankfin.2017.12.010

Blau, T. H. (1977). Quality of life, social indicators, and criteria of change. Professional Psychology: Research and Practice, 8(4), 464-473. https://psycnet.apa.org/doi/10.1037/0735-7028.8.4.464 
Blinco, S., Galbarz, M., Hohl, S., \& Zamil, R. (2020). Bank boards - a review of post-crisis regulatory approaches FSI Insights on policy implementation. No 25, Bank for International Settlements.

Bøhren, Ø., \& Staubo, S. (2016). Mandatory gender balance and board independence. European Financial Management, 22(1), 3-30. https://doi.org/10.1111/eufm.12060

Bøhren, Ø., \& Strøm, R. Ø. (2010). Governance and Politics: Regulating Independence and Diversity in the Board Room. Journal of Business Finance and Accounting, 37(9-10), 1281-1308. https://doi.org/10.1111/j.1468-5957.2010.02222.x

Bongini, P., Cucinelli, D., Di Battista, M. L., \& Nieri, L. (2019). Profitability shocks and recovery in time of crisis evidence from European banks. Finance Research Letters, 30, 233-239. https://doi.org/10.1016/j.frl.2018.10.003

Cardillo, G., Onali, E., \& Torluccio, G. (2020). Does gender diversity on banks' boards matter? Evidence from public bailouts. Journal of Corporate Finance, 101560. https://doi.org/10.1016/j.jcorpfin.2020.101560

Carter, D. A., Simkins, B. J., \& Simpson, W. G. (2003). Corporate governance, board diversity, and firm value. Financial Review, 38(1), 33-53. https://doi.org/10.1111/1540-6288.00034

Dameri, R. P., Garelli, R., \& Resta, M. (2020). Neural networks in accounting: Clustering firm performance using financial reporting data. Journal of Information Systems, 34(2), 149-166. https://doi.org/10.2308/isys-18-002

De Haan, J., \& Vlahu, R. (2016). Corporate governance of banks: A survey. Journal of Economic Surveys, 30(2), 228-277. https://doi.org/10.1111/joes.12101

De Andres, P., \& Vallelado, E. (2008). Corporate governance in banking: The role of the board of directors. Journal of Banking and Finance, 32(12), 2570-2580. https://doi.org/10.1016/j.jbankfin.2008.05.008

Ding, C., \& He, X. (2004). K-means Clustering via Principal Component Analysis. Proceedings of the $21^{s t}$ International Conference on Machine Learning, Banff, Canada, 2004. https://doi.org/10.1145/1015330.1015408

European Banking Authority-European Securities and Markets Authority [EBA-ESMA]. (2017). Guidelines on the Assessment of Suitability of Members of the Management Body and Key Function Holders, EBA-GI-2017-12.

European Banking Authority-European Securities and Markets Authority [EBA-ESMA]. (2021). Joint ESMA and EBA Guidelines on the assessment of the suitability of members of the management body (revised).

European Central Bank [ECB]. (2018). Guide to fit and proper assessments. Updated in May 2018 in line with the joint ESMA and EBA Guidelines on suitability

European Central Bank [ECB]. (2021). ECB launches consultation on its revised Guide to fit and proper assessments. Press release 15 June 2021

Ellul, A., \& Yerramilli, V. (2013). Stronger Risk Controls, Lower Risk Evidence from US Bank Holding Companies. Journal of Finance, 68, 1757-1803. https://doi.org/10.1111/jofi.12057

Farrell, K. A., \& Hersch, P. L. (2005). Additions to corporate boards: the effect of gender. Journal of Corporate Finance, 11(1-2), 85-106. https://doi.org/10.1016/j.jcorpfin.2003.12.001

Farnè, M., \& Vouldis, A. T. (2020). Does a bank's business model affect its capital and profitability? Economic Notes, 49(2), e1216. https://doi.org/10.1111/ecno.12161

Fernandes, C., Farinha, J., Martins, F. V., \& Mateus, C. (2018). Bank governance and performance: A survey of the literature. Journal of Banking Regulation, 19, 236-256. https://doi.org/101057/s41261-017-0045-0

Fiordelisi, F., \& Marques-Ibanez, D. (2013). Is bank default risk systematic? Journal of Banking and Finance, 37(6), 2000-2010. https://doi.org/10.1016/j.jbankfin.2013.01.004

FSB - Financial Stability Board. (2013). Thematic Review on Risk Governance.

FSB - Financial Stability Board. (2017). Thematic Review on Corporate Governance.

García-Meca, E., García-Sànchez, I. M., \& Martínez-Ferrero, J. (2015). Board diversity and its effects on bank performance: An international analysis. Journal of Banking and Finance, 53(1), 202-214. https://doi.org/10.1016/j.jbankfin.2014.12.002

Gorban, A. N., Kegl, B., Wunsch, D., \& Zinovyev, A. (Eds). (2007). Principal Manifolds for Data Visualisation 
and Dimension Reduction. Lecture Notes in Computational Science and Engineering, 58.

Grove, H., Patelli, L., Victoravich, L. M., \& Xu, P. (2011). Corporate governance and performance in the wake of the financial crisis: Evidence from US commercial banks. Corporate Governance: An International Review, 19(5), 418-436. https://doi.org/10.1111/j.1467-8683.2011.00882.x

Hanafizadeh, P., \& Mirzazadeh, M. (2011). Visualizing market segmentation using self-organizing maps and Fuzzy Delphi method - ADSL market of a telecommunication company. Expert Systems with Applications, 38(1), 198-205. https://doi.org/10.1016/j.eswa.2010.06.045

Harkin, S., Mare, D., \& Crook, J. (2020). Independence in bank governance structure: Empirical evidence of effects on bank risk and performance. Research in International Business and Finance, 52, 101177. https://doi.org/10.1016/j.ribaf.2019.101177

Hartigan, J., \& Wang, M. (1979). A K-means clustering algorithm. Journal of the Royal Statistical Society. Series C (Applied Statistics), 28, 100-108. http://dx.doi.org/10.2307/2346830

Hau, H., \& Thum, M. (2009). Subprime crisis and board (in-) competence: private versus public banks in Germany. Economic Policy, 24(60), 701-752. https://doi.org/10.1111/j.1468-0327.2009.00232.x

Hermalin, B. E., \& Weisbach, M. S. (1991). The effects of board composition and direct incentives on firm performance. Financial management, 20(4), 101-112. https://doi.org/10.2307/3665716

Hermalin, B. E., \& Weisbach, M. S. (2003). Board of directors as an endogenously-determined institution: A survey of the economic literature. Economic Policy Review, 9, 7-26.

John, K., De Masi, S., \& Paci, A. (2016). Corporate governance in banks. Corporate Governance: An International Review, 24(3), 303-321. https://doi.org/10.1111/corg.12161

Kirkpatrick, G. (2009). The corporate governance lessons from the financial crisis. Financial Market Trends, OECD.

Kohonen, T. (1982). Self-organized formation of topologically correct feature maps. Biological Cybernetics, 43, 59-69. https://doi.org/10.1007/BF00337288

Kohonen, T. (1997). Self-organized maps. Springer-Verlag, Berlin Heidelberg.

Kolari, J. W., \& Sanz, I. P. (2017). Systemic risk measurement in banking using self-organizing maps. Journal of Banking Regulation, 18(4), 338-358.

Lee, J. B., \& Megrey, B. A. (2010). On the utility of self-organizing maps (SOM) and k-means clustering to characterize and compare low frequency spatial and temporal climate impacts on marine ecosystem productivity. International Symposium on Climate Change Effects on Fish and Fisheries

Locatelli, R., Schena, C., Tanda, A., \& Uselli, A. (2018). Diversity measures and quality of banks' boards: the Italian case. Journal of Financial Management, Markets and Institutions, 6(2), 1850009. https://doi.org/10.1142/S2282717X18500093

Mehran, H., Morrison, A. D., \& Shapiro, J. D. (2011). Corporate governance and banks: What have we learned from the financial crisis? FRB of New York Staff Report, (502)

Masulis, R.W., Wang, C., \& Xie, F. (2012). Globalizing the boardroom-The effects of foreign directors on corporate governance and firm performance. Journal of Accounting and Economics 53(3), 527-554. https://doi.org/10.1016/j.jacceco.2011.12.003

Minton, B. A., Taillard, J. P., \& Williamson, R. (2014). Financial expertise of the board, risk taking, and performance: Evidence from bank holding companies. Journal of Financial and Quantitative Analysis, 49(2), 351-380. https://doi.org/10.1017/S0022109014000283

Mints, A. (2019). Analysis of the stability factors of Ukrainian banks during the 2014-2017 systemic crisis using the Kohonen self-organizing neural networks. Banks and Bank Systems, 14(3), 86.

Nguyen, D. D. L., Hagendorff, J., \& Eshraghi, A. (2015). Which Executive Characteristics create Value in Banking? Evidence from Appointment Announcements. Corporate Governance: An International Review, 23(2), 112-128. https://doi.org/10.1111/corg.12084

Pathan, S., \& Faff, R. (2013). Does board structure in banks really affect their performance? Journal of Banking and Finance, 37(5), 1573-1589. https://doi.org/10.1016/j.jbankfin.2012.12.016

Pearson, K. (1901). On Lines and Planes of Closest Fit to Systems of Points in Space. Philosophical Magazine, 
2(11), 559-572. https://doi.org/10.1080/14786440109462720

Resta, M. (2022). Pandemic spreading in Italy and Regional policies: An approach with self-organizing maps. Handbook of Artificial Intelligence in Healthcare, 2, 199-213. Springer, Cham.

Resti, A. C. (2020). Is the current "fit and proper" regime appropriate for the Banking Union? In-Depth Analysis. Requested by the ECON committee, PE 624442

Sarlin, P., Yao, Z., \& Eklund, T. A. (2012). Framework for State Transitions on The Self-Organizing Map: Some Temporal Financial Applications. Philosophical Magazine 19(1), 189-203. https://doi.org/10.1002/isaf.1328

Schultz, E. L., Tan, D. T., \& Walsh, K. D. (2010). Endogeneity and the corporate governance-performance relation. Australian journal of Management, 35(2), 145-163. https://doi.org/10.1177/0312896210370079

Sheikh, M. F., Shah, S. Z. A., \& \& Akbar, S. (2018). Firm performance, corporate governance and executive $\begin{array}{llll}\text { compensation in } & \text { Pakistan. }\end{array}$ https://doi.org/10.1080/00036846.2017.1386277

Somers, M. J., Casal, J. (2017). Introducing Neural Computing in Governance Research: Applying SelfOrganizing Maps to Configurational Studies. Corporate Governance: An International Review, 25(6), 440-453. http://doi.org/10.1111/corg.12173

Srivastav, A., \& Hagendorff, J. (2016). Corporate governance and bank risk-taking. Corporate Governance: An International Review, 24(3), 334-345. https://doi.org/10.1111/corg.12133

Sun, J., \& Cahan, S. (2009). The effect of compensation committee quality on the association between CEO cash compensation and accounting performance. Corporate Governance: An International Review, 17(2), 193-207. https://doi.org/10.1111/j.1467-8683.2008.00726.x

Tarchouna, A., Jarraya, B., \& Bouri, A. (2017). How to explain non-performing loans by many corporate governance variables simultaneously? A corporate governance index is built to US commercial banks. Research in International Business and Finance, 42, 645-657. https://doi.org/10.1016/j.ribaf.2017.07.008

Toor, A. K., \& Singh, A. (2013). Analysis of Clustering Algorithms Based on Number of Clusters, Error Rate, Computation Time and Map Topology on Large Data Set. International Journal of Emerging Trends \& Technology in Computer Science, 2(6), 94-98.

Willshaw, D. J., \& von der Malsburg, C. (1976). How patterned neural connections can be set up by self-organization. Proceedings of the Royal Society, London series B, 194, 431-445. https://doi.org/10.1098/rspb.1976.0087

Willshaw, D. J., \& von der Malsburg, C. (1979). A marker induction mechanism for the establishment of ordered neural mappings: Its application to the retinotectal problem. Philosophical Transactions of the Royal Society, London, Series B, 287, 203-243. https://doi.org/10.1098/rstb.1979.0056

Wintoki, M. B., Linck, J. S., \& Netter, J. M. (2012). Endogeneity and the dynamics of internal corporate governance Journal of Financial Economics, 105(3), 581-606. https://doi.org/10.1016/j.jfineco.2012.03.005

Yeung, K. Y., \& Ruzzo, W. L. (2001). Principal component analysis for clustering gene expression data. Bioinformatics, 17(9), 763-774. https://doi.org/10.1093/bioinformatics/17.9.763

Zou, H., \& Hastie, T. (2005). Regularization and variable selection via the elastic net. Journal of the Royal $\begin{array}{llllll}\text { Statistical Society: } \quad \text { Series } & B & \text { (Statistical }\end{array}$ https://doi.org/10.1111/j.1467-9868.2005.00503.x

\section{Notes}

Note 1. More specifically, Article 91.

Note 2. For instance, to synthesize at the board level the attainment of a bachelor's degree, we compute the incidence of graduated directors over the total number of directors. For independence and balance of power, and time commitment we compute respectively the percentage of independent directors, non-executive directors seated in the board and the average presence at boards' meetings. For diversity, we compute the relative presence of a given feature in the board (e.g., women, foreign directors, percentage of directors with a degree in a specific area or specific expertise - such as economics, banking, law, etc.) (see Table 2).

Note 3. Considering the different governance models included in the sample that rely on different types of management bodies, we considered all the directors sitting in any of the management bodies of the bank, e.g., 
management and supervisory boards for two-tier model; board of directors for one-tier model; board of directors and board of auditors for the other models.

Note 4. The B\&F score ranges from 0 to 5 . We assign one point for the professional experience made by the director in one of the following positions: manager or director of a financial institution, consultant, or professor/academic linked to financial systems. As an example, if the director has at least one experience in a given category (e.g., the director was manager of one or more banks), we assign 1 point. If the director has experience in all the categories, the score is 5 (maximum). The rationale of the score is that the higher the scope of the professional experience made by the director in the financial system, the wider and stronger his/her knowledge. By construction, this score does not take into account the length of each experience because this information is available only seldom. The B\&F score of the board is the average of the board members B\&F scores.

Note 5. The DNA Matrix works in the neural space and visualizes how close representative neurons (i.e., the neurons mapping banks) are one to one another; this, in turn, may help in understanding the closeness of the banks therein mapped.

Note 6. Board Archetypes are generated by SOMs based on governance characteristics as recorded at the end of 2014. The SOM, in its standard configuration, is not suitable to track changes in governance features over time. We could, in fact, apply SOMs algorithm to data related to other years, but each application would generate new archetypes that are not comparable with those of previous/following years in terms of number and features. In a future perspective applying the T-SOM algorithm of Sarlin et al. (2012) might provide some insight for a dynamic understanding of the governance features.

Note 7. In contrast to other empirical analyses (Anginer et al., 2018; Fan et al., 2019), we cannot address potential endogeneity using a panel regression with fixed effect, because the independent variables of interest archetypes - are time-invariant dummies. This characteristic also prevents us from applying dynamic GMM, i.e., a methodology that is increasingly exploited in the governance empirical literature (Schultz et al., 2010; Sheikh et al., 2018; Wintoki et al., 2012). Both difference and system GMM, in fact, remove the fixed effects within a panel when the equations to be estimated are differenced. Another seldom-used approach in the governance-performance literature is IV-regression. However, similarly to other studies, we could not find one (or more) suitable instrumental variable(s), considering all the board features already included in our analysis (see discussion by Aebi et al., 2012)

Note 8. See Appendix A.

Note 9. The Blau Index (Blau, 1977) is computed as $B=1-\sum_{i=1}^{k} p_{i}{ }^{2}$, where $\mathrm{p}$ is the percentage of directors in a given category, and $\mathrm{k}$ is the total number of categories and it varies between 0 (minimum diversity) and $(\mathrm{k}-1) / \mathrm{k}$ (maximum diversity).

Note 10. As noted by Hermalin and Weisbach (1991), differently from earning measures, stock returns are more influenced by investors' expectations rather than by the actual/recent bank situation. This may explain why the stock-market performance is less influenced than ROA and ROE by the governance archetype.

Note 11. In unreported regressions we employ alpha - computed as the intercept when regressing excess bank return on excess market return following the CAPM model - as a measure of market risk-adjusted return; however, results are inconclusive and statistically insignificant.

Note 12. Results are omitted for the sake of synthesis and are available upon request.

\section{Appendix A}

\section{The SOM algorithm}

The SOM algorithm is an ensemble of computational tasks aimed at mimicking the neurobiological process, which maps different sensory inputs onto corresponding areas of the cerebral cortex in an orderly fashion The key elements in the biological process are competitive learning and the "winner takes all" principle: all the units are excited with the same signal, but only one will produce the highest response thus automatically becoming a candidate to the receptive basin for that specific pattern The Self-Organizing algorithm goes one-step further, generalizing the "winner takes all" idea into that of the winner taking the most According to this principle, when a pattern is presented to the SOM, the related information is retrieved not only by the best neuron, but also by its closest neighbors, according to a proper (mathematical) similarity criterion In this way, neurons in the map organize themselves, and connectivity structures are formed, which are topology-preserving with respect to input 
data, that is: similar input items are located close to each other in the 2-D projection plane

The SOM training can be summarized in the following steps performed in a sequential way Let us denote by $\boldsymbol{x}$ an input pattern, then:

1) Evaluate the distance between $\boldsymbol{x}$ and each neuron of the SOM;

2) Select the neuron (node) with the smallest distance from $\boldsymbol{x}$ This is the winner neuron or Best Matching Unit (BMU);

3) Correct the position of each node according to the results of Step 2, in order to preserve the network topology

Steps 1-3 can be repeated either once or more than once for each input pattern: a good stopping criterion generally consists in taking a view to the Quantization Error (QE), i.e., a weighted average over the Euclidean norms of the difference between the input vector and the corresponding BMU When QE goes below a proper threshold level, say for instance $10^{-2}$ or lower, it might be suitable to stop the procedure In this way, once the learning procedure is concluded, the organization of the SOM is the projection of the input space into a lower dimensional space with closer nodes representing neighbor input patterns.

\section{Copyrights}

Copyright for this article is retained by the author(s), with first publication rights granted to the journal.

This is an open-access article distributed under the terms and conditions of the Creative Commons Attribution license (http://creativecommons.org/licenses/by/4.0/). 